\title{
Analisis jumlah volume bahan bakar yang dihasilkan pada alat pirolisis sampah plastik tipe LDPE
}

\author{
Ari Kurniawan ${ }^{1 *}$, Basuki ${ }^{2}$, Mochamad Arif Irfa ${ }^{\circledR}{ }^{3}$ \\ 1,2,3Prodi Teknik Mesin, Fakultas Teknik, Universitas Hasyim Asy'ari \\ Jl. Irian Jaya 55 Tebuireng Tromol Pos IX Jombang Jatim Telp. (0321) 861719 (Hunting), \\ 864206, 851396, 874685 Fax. 874684 \\ ${ }^{*}$ Corresponding author: arikurniawan151998@gmail.com
}

\begin{abstract}
The research in this article is a discussion of the analysis of the total volume of fuel produced in the LDPE type plastic waste pyrolysis tool. The purpose of this study was to utilize LDPE plastic waste into alternative fuels by using a temperature of $300^{\circ} \mathrm{C}$ in a pyrolysis device. Testing of the pyrolysis tool obtained data from each test, namely at a temperature of $300^{\circ} \mathrm{C}$ it produced oil with an average of $400 \mathrm{ml}$.
\end{abstract}

Keywords: Pyrolysis Oil, pyrolysis, LDPE Plastic

\begin{abstract}
Abstrak
Penelitian pada artikel ini merupakan pembahasan analisis jumlah volume bahan bakar yang dihasilkan pada alat pirolisis sampah plastik tipe LDPE. Tujuan penelitian ini adalah memanfaatkan limbah sampah plastik tipe LDPE menjadi bahan bakar alternatif dengan menggunakan suhu $300^{\circ} \mathrm{C}$ pada alat pirolisis. Pengujian alat pirolisis didapatkan data dari masing-masing pengujian yaitu pada suhu $300^{\circ} \mathrm{C}$ menghasilkan minyak dengan rata-rata 400 $\mathrm{ml}$.

Kata kunci: Minyak pirolisis, Pirolisator, Plastik LDPE
\end{abstract}

\section{Pendahuluan}

Permasalahan yang dihadapi dunia pada khususnya di Indonesia seperti masalah pencemaran lingkungan diakibatkan banyak sampah plastik yang tidak terurai dengan mudah oleh mikroorganisme. Pengembangan bahan alternatif pembuatan plastik bertujuan untuk mengurangi dampak pencemaran sampah plastik dengan mengembangkan kemasan biodegradable [1]. Penggunaan barang yang berbahan plastik semakin meningkat sejak ditemukannya pertama kali pada tahun 1907. Meningkatnya pemakainan plastik ini merupakan konsekuensi yang ditimbulkan dari perkembangan teknologi, industri serta meningkatnya jumlah penduduk. Indonesia merupakan peringkat kedua sebagai negara penyumbang sampah plastik terbesar didunia setelah China. Berdasarkan dari data memaparkan penghasilan sampah plastik di Indonesia yang mencapai 187,2 juta ton dan sebelumnya China telah mencapai 262,9 juta ton per tahun [2].

Plastik biodegradable merupakan plastik yang dapat digunakan layaknya seperti plastik konvensional, namun akan hancur terurai oleh aktivitas mikroorganisme setelah habis terpakai dan dibuang ke lingkungan. Biasanya plastik konvensional berbahan dasar petroleum, gas alam, atau batu bara. Sementara plastik biodegradable terbuat dari material yang dapat diperbaharui, yaitu dari senyawasenyawa yang terdapat dalam tanaman misalnya pati, selulosa, kolagen, kasein, protein atau lipid yang terdapat dalam hewan [3]. Peningkatan sampah plastik ini menimbulkan permasalahan bagi lingkungan. Penyebabnya dari sifat plastik yang tidak mudah terurai secara alami, hal ini dikarenakan plastik yang beredar merupakan polimer sintetik yang terbuat dari minyak bumi, sehingga untuk dapat menguraikan sampah plastik secara alami 
membutuhkan waktu 100 tahun agar plastik dapat terurai secara sempurna [4].

Warga Indonesia merupakan masyarakat yang mempergunakan bendabenda berbahan plastik karena sangat memudahkan dalam pembawaan atau dalam pengemasan makanan. Plastik yang berjenis LDPE (Low Density Polythilene) banyak tersebar di masyarakat Indonesia sebab plastik yang berjenis LDPE bersifat lentur, tidak kaku, tidak robek, kuat, serta harga plastik relatif murah atau rendah. Plastik berjenis plastik LDPE memiliki dampak negatif jika proses pengolahannya tidak benar maka berimbas pada kerusakan lingkungan. Telah banyak metode yang dikembangkan, mulai dari pembakaran atau insinerasi di udara terbuka, namun hasilnya berupa gas racun seperti gas $\mathrm{CO}$, furan, dioxin, dan logam berat seperti kromium, kobalt, tembaga, timbal, selenium, dan cadmium yang merupakan semua zat-zat tersebut berbahaya untuk kesahatan masyarakat [5].

Kemudian ada metode reuse dan reycle namun tidak dapat menanggulangi secara efektif untuk mesalah sampah plastik, lalu muncul metode penaggulangan sampah plastik yaitu menjadikan sampah plastik sebagai bahan bakar cair dengan proses pirolis. Pirolisis adalah proses pembakaran material anorgranik atau sintetis dalam keadaan sedikit oksigen dengan memanfaatkan panas dari pembakaran dalam keadaan temperatur tinggi. Plastik yang merupakan polimer rantai panjang akan terurai menjadi senyawa rantai pendek. Energi alternatif yang dihasilkan dari pengolahan sampah plastik menggunakan proses pirolisis yaitu berupa bahan bakar minyak. Pengolahan sampah plastik menjadi bahan bakar minyak, selain dapat mengurangi sampah plastik di masyarakat maka kita juga ikut menghemat persediaan minyak bumi di alam [4].

Sampah plastik dapat diubah menjadi minyak dikarenakan pada dasarnya pembuatan plastik berasal dari minyak bumi, jadi sampah plastik tersebut seolah mengalami proses daur ulang. Selain itu minyak yang dihasilkan dari pengolahan sampah plastik tersebut memiliki nilai kalor yang cukup tinggi setara dengan bahan bakar fosil yang berupa bensin dan solar [6].

Penelitian analisis pengaruh suhu terhadap volume bahan bakar yang dihasilkan pada alat pirolisis sampah plastik tipe LDPE ini bertujuan untuk mengurangi sampah plastik yang mencemari lingkungan di masyarakat Indonesia serta upaya untuk menjadikan sampah plastik menjadi sumber energi alternatif dengan cara pengubahan sampah plastik menjadi bahan bakar minyak menggunakan metode pirolisis.

\section{Tinjauan Pustaka}

Energi adalah suatu kemampuan untuk melakukan suatu usaha. Energi merupakan besaran yang kekal, maksudnya energi tidak dapat diciptakan dan dimusnahkan, tetapi dapat diubah ubah dari bentuk satu kebentuk yang lain. Energi dapat dibedakan menjadi dua antara lain:

a. Energi tak terbarukan (konvensional)

Sumber energi tak terbarukan adalah sumber energi yang diambil dari sumber daya alam yang apabila digunakan secara terus menerus akan habis atau sumber yang hanya tersedia dalam jumlah terbatas. Sumber energi ini yaitu berasal dari minyak bumi, fosil, dan gas alam.

b. Energi terbarukan

Konsep energi terbarukan ini diperkenalkan pada tahun 1970 sebagai usaha pergerakan melewati pengembangan bahan bakar nuklir dan fosil. Definisis paling umum yaitu sumber energi yang dapat diisi kembali oleh alam atau merupakan proses berkelanjutan. Contoh energi terbarukan antara lain yaitu: angin, matahari, panas bumi, biofuel, air, biomassa, bioethanol (pirolisis) dan lain-lain.

Pirolisis adalah cara fraksinasi material yang disebabkan oleh temperatur. Pirolisis termasuk proses penguraian material anorganik atau sintesis dalam keadaan sedikit oksigen dengan 
memanfaatkan panas dari pembakaran dalam keadaan temperatur tinggi [5]. Cara kerja alat pirolisis adalah dengan memanaskan plastik pada tabung reaktor dengan tanpa oksigen dalam temperatur tertentu. Selama proses pembakaran plastik akan mencair kemudian plastik mengalami penguapan (gas). Setelah itu, uap hasil pembakaran sampah plastik akan diteruskan melalui pipa pendingin dan uap mengalami proses penyubliman sehingga berubah menjadi zat cair. Zat cair itulah yang menjadi minyak mentah, cikal bakal dari bahan bakar minyak [7].

Plastik merupakan salah satu jenis macromolekul yang terbentuk dari proses polimersasi. Polimersasi yaitu proses penggabungan antara beberapa molekul sederhana (monomer) melalui proses kima dan menghasilkan molekul besar yang disebut polimer. Plastik termasuk senyawa polimer yang unsur penyusunannya adalah hydrogen dan karbon [8].

Plastik LDPE merupakan jenis plastik sintetik yang memiliki sifat nonbiodegradable atau tidak dapat terdegradasi oleh mikroganisme, sehingga dapat menimbulkan masalah pada lingkungan. Contoh dari jenis sampah LDPE antara lain yaitu, kantong makanan, kantong roti, botol minuman, plastik kemasan dan lain-lain [9].

\section{Metode Penelitian}

Pada penelitian yang memfokuskan pada rancang bangun alat pirolisis sampah plastik tipe LDPE dan analisis volume bahan bakar alternatif yag dihasilkan dengan menggunakan metode eksperimental dengan proses penelitian secara bertahap untuk menunjukkan sebab-akibat antara dua variabel ataupun lebih, dengan mengatur variabel bebas secara sengaja pada objek penelitian yang bertujuan untuk mengetahui pengaruhnya bertahap variabel terikat [10].

Variabel yang digunakan dalam penelitian ini adalah sebagai berikut:

\section{a. Variabel Bebas}

Variabel bebas merupakan variabel yang mempengaruhi atau penyebab beberapa faktor yang akan diukur dan dimanipulasi oleh peneliti. Tujuannya untuk mengetahui hubungan kejadian yang diamati oleh peneliti. Pada penelitian ini variabel bebasnya yaitu jumlah volume minyak yang dihasilkan pada suhu $300^{\circ} \mathrm{C}$.

b. Variabel Terikat

Variabel terikat yaitu suatu faktor yang dapat diobservasi dan dapat diukur dengan tujuan untuk mengetahui pengaruh dari variabel bebas. Variabel terikat yang dapat diambil dalam penelitian ini yaitu, hasil dari jumlah bahan bakar minyak (ml) yang didapat dari proses pirolisis.

c. Variabel Kontrol

Variabel kontrol adalah bentuk variabel yang dapat dikendalikan dan bisa mempengaruhi variabel bebas terhadap variabel dependen atau variabel tergantung, dan tidak dapat dipengaruhi oleh faktor dari luar yang tidak diteliti. Variabel kontrol yang dapat diambil yaitu jenis plastik yang digunakan adalah plastik LDPE dengan berat minimal $1 \mathrm{~kg}$, alat yang digunakan yaitu alat pirolisis, waktu proses pirolisis yang digunakan selama 1 jam, air pendingin menggunakan air es dengan suhu $25^{\circ} \mathrm{C}$.

Berikut ini merupakan desain alat pirolisis sampah plastik dapat dilihat pada Gambar 2 dibawah ini:

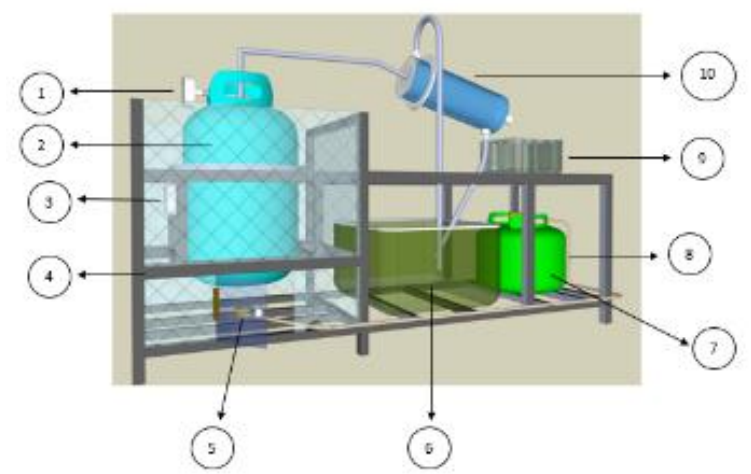

Gambar 1. Alat Pirolisis

Keterangan gambar:

1. Regulator (pengukur tekanan uap)

2. Tungku pembakaran

3. Termometer pengukur suhu 
4. Rangka

5. Kompor

6. Bak penampung air pendingin (air es)

7. Tabung gas LPG $3 \mathrm{~kg}$

8. Pipa Gas

9. Bak penampung BBM (bahan bakar minyak)

10. Kondensor (alat pendingin)

\section{Teknik Pengumpulan Data}

Teknik pengumpulan data ini bertujuan untuk mendapatkan data atau informasi yang baik dan terstruktur serta memastikan keakuratan dalam setiap penelitian. Sehingga kebenaran dari informasi yang diperoleh dan dapat dipertanggung jawabkan. Adapun teknik pegumpulan data yang digunakan dalam penelitian ini, yaitu:

a. Observasi

Merupakan suatu teknik pengumpulan data dengan cara mengamati langsung terhadap objek yang diteliti da pencatatan secara sistematik terhadap objek penelitian. Observasi yang dilakukan pada penelitian ini bertujuan untuk mengetahui hasil dari perbandingan tiap-tiap baha bakar pada alat pirolisis.

b. Dokumentasi

Pengumpulan data dengan teknik dokumentasi yaitu dengan menghimpun dan menganalisis dokumen, baik berupa dokumen tertulis, gambar, maupun elektronik. Teknik dokumentasi dalam penelitian ini berupa dokumentasi proyek dan dokumentasi tertulis.

c. Studi Literatur

Dengan melakukan kajian dari berbagai journal, buku, artikel untuk mendapatkan teori dan rumus. Dilakukannya studi literatur dalam teknik pengumpulan data yaitu bertujuan untuk mencari dasar pengambilan sebuah informasi tentang data dalam penelitian ini.

\section{d. Eksperimen}

Dengan melakukan uji coba pada objek penelitian untuk proses pengambilan data dari hasil studi literatur. Pada tahapan ini, dilakukannya pengujian terhadap objek penelitian pada suhu $300^{\circ} \mathrm{C}$ terhadap jumlah hasil pirolisis yang didapatkan.

\section{Teknik Analisis Data}

Pada tahap ini peneliti melakukan analisis data dengan menggunakan analisis perbandingan atau komparasi yang didapat dari beberapa data yaitu:

a. Perbedaan pada setiap pengujian di suhu $300^{\circ} \mathrm{C}$ terhadap proses pembakaran pada alat pirolisis

b. Efektifitas dari alat pirolisis sampah plastik

c. Data yang diperoleh akan dibuat grafik

\section{Hasil dan Pembahasan}

Pada pengujian di suhu pembakaran $300^{\circ} \mathrm{C}$ dalam waktu 1 jam terhadap sampah plastik LDPE seberat $1 \mathrm{~kg}$, didapatkan hasil seperti pada Tabel 1.

Tabel 1. Perbandingan jumlah minyak, arang pembakaran, dan massa gas LPG pada setiap pengujian.

\begin{tabular}{|c|c|c|c|c|}
\hline \multicolumn{5}{|c|}{ PENGUJIAN PADA SUHU $300^{\circ} \mathrm{C}$} \\
\hline & & Hasil & Arang & Massa \\
\hline & & $\begin{array}{l}\text { Minyak } \\
(\mathrm{ml})\end{array}$ & $\begin{array}{l}\text { Pembakaran } \\
\text { (gram) }\end{array}$ & $\begin{array}{c}\text { Gas LPG } \\
(\mathrm{Kg})\end{array}$ \\
\hline \multirow{3}{*}{ Pengujian } & 1 & 400 & 533 & 0,6 \\
\hline & 2 & 410 & 517 & 0,7 \\
\hline & 3 & 390 & 543 & 0,6 \\
\hline Rata-rata & & 400 & 531 & 0,63 \\
\hline \multicolumn{5}{|c|}{$\begin{array}{l}\text { - Pengujian menggunakan sampah plastik } L D P E \\
\text { dengan massa } 1 \mathrm{Kg} \text {. } \\
\text { - Lama waktu pembakaran } 1 \mathrm{Jam} \text { (60 menit). }\end{array}$} \\
\hline
\end{tabular}

Berdasarkan pada Tabel 1 dapat dijelaskan bahwa pada pengujian pertama minyak yang dihasilkan sebanyak $400 \mathrm{ml}$ dengan hasil arang sisa pembakaran seberat 533 gram dan menghabiskan massa gas LPG sebanyak $0,6 \mathrm{~kg}$. Untuk pengujian kedua minyak yang dihasilkan sebesar $410 \mathrm{ml}$ dengan hasil arang sisa pembakaran seberat 517 gram dan menghabiskan massa gas LPG sebanyak $0,7 \mathrm{~kg}$. Sedangkan pada pengujian ketiga minyak yang dihasilkan sebanyak $390 \mathrm{ml}$ dengan hasil arang sisa pembakaran seberat 543 gram dan menghabiskan massa gas LPG sebanyak 0,6 kg. 
Berdasarkan dari hasil pengujian diambil nilai hasil rata-rata minyak, arang pembakaran, dan massa gas LPG dapat dilihat perbedaan dari setiap pengujian pada masing-masing suhu, dapat melihat grafik pada gambar 2, 3, dan 4 sebagai berikut:

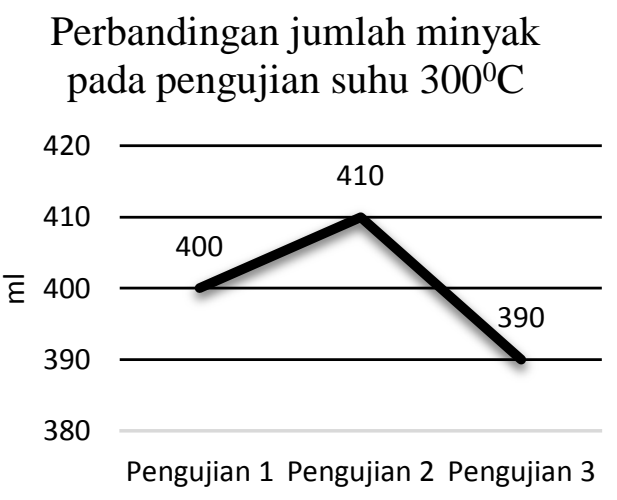

Gambar 2. Grafik perbandingan jumlah minyak pada suhu $300^{\circ} \mathrm{C}$.

Grafik pada Gambar 2 menjelaskan perbandingan volume minyak di setiap pengujian pada suhu $300^{\circ} \mathrm{C}$ dengan hasil minyak pada pengujian 1 sebesar $400 \mathrm{ml}$, pengujian ke 2 minyak yang didapat sebesar $410 \mathrm{ml}$, sedangkan pada pengujian 3 jumlah minyak yang didapat sebesar $390 \mathrm{ml}$ dengan jumlah minyak rata-rata pada ke tiga pengujian yaitu $400 \mathrm{ml}$.

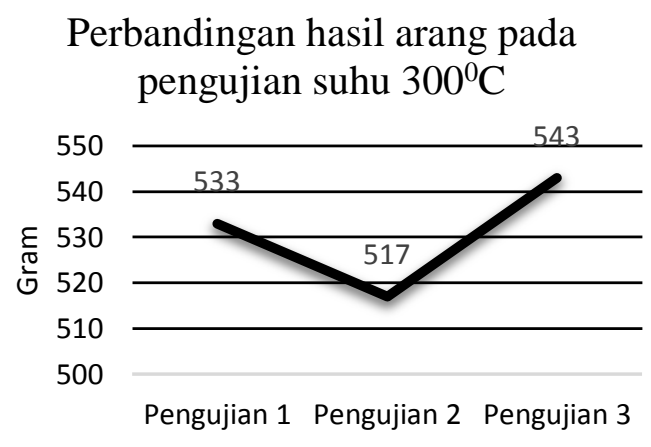

Gambar 3. Grafik Perbandingan Hasil Arang Pada Suhu $300^{\circ} \mathrm{C}$.

Diagram pada Gambar 3 menjelaskan perbandingan hasil arang pembakaran di setiap pengujian pada suhu $300^{\circ} \mathrm{C}$ dengan hasil arang yang didapat pada pengujian 1 sebesar 533 gram, di pengujian 2 hasil arang yang didapat sebesar 517 gram, sedangkan di pengujian 3 hasil arang yang didapat sebesar 543 dengan jumlah rata-rata yang dapat diambil dari ketiga pengujian yaitu 531 gram.

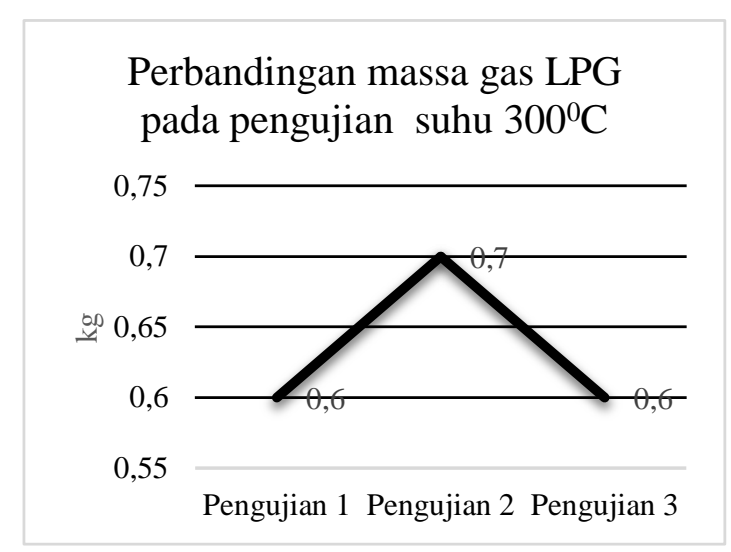

Gambar 4. Grafik perbandingan massa gas LPG yang terpakai pada suhu $300^{\circ} \mathrm{C}$.

Pada diagram Gambar 4 menjelaskan massa gas LPG yang terpakai disetiap pengujian pada suhu $300^{\circ} \mathrm{C}$ dengan massa gas LPG yang terpakai pada pengujian 1 sebesar 0,6 kg, kemudian di pengujian 2 massa gas LPG yang terpakai sebesar $0,7 \mathrm{~kg}$, sedangkan pada pengujian 3 massa gas LPG yang terpakai sebesar $0,6 \mathrm{~kg}$. Berdasarkan disetiap pengujian jumlah ratarata gas LPG yang terpakai sebesar $0,63 \mathrm{~kg}$.

\section{Kesimpulan}

Hasil dari penelitian yang telah dilaksanakan dapat disimpulkan bahwa, hasil pengujian alat pada suhu $300^{\circ} \mathrm{C}$ dapat menghasilkan minyak dengan rata-rata sebesar $400 \mathrm{ml}$, dengan jumlah arang dengan rata-rata 531 gram, dan massa gas LPG yang terpakai dengan jumlah rata-rata sebesar $0,63 \mathrm{~kg}$. Untuk mendapatkan hasil minyak yang maksimal, maka penelitian selanjutnya disarankan utuk meningkatkan suhu pembakaran. Suhu pembakaran yang kurang tinggi menyebabkan lambatnya proses peleburan.

\section{Referensi}

[1] Hudha, Istnaeny M dkk. 2020. "Potensi Limbah Keju (Whey) sebagai Bahan Pembuatan Plastik Pengemas yang Ramah Lingkungan“. 
Malang: Jurnal Teknik: Media Pengembangan Ilmu.

[2] Mursito, A.J., Sukadana, K.G., Tenaya, P.N.G., 2017.” Perancangan dan Pengujian Alat Destilasi Minyak Dari Limbah Sampah Plastik".Vol. 6(4): hal. 311- 377.

[3] Nugroho, A.C.S., dan Linggar, A.O., 2017." Sintesis Dan Karakterisasi Bioplastik Dari Kitosan-Pati Ganyong (Canna Edulis)“. Vol. 2(1): hal. 13-21.

[4] Tahir, R., Alwathan. 2014." Pengambilan Fraksi Ringan Produk Hasil Pirolisis Limbah Plastik Jenis Polipropilene (Pp) Dengan Metode Destilasi Fraksionasi Bubble Cap". Vol. 3(2).

[5] Mandala, W.W., Cahyono, S.M., Ma'arif, S., Sukarjo, B.H., Wardoyo. 2016. "Pengaruh Suhu terhadap Rendemen dan Nilai Kalor Minyak Hasil Pirolisis Sampah Plastik". Vol. 1(2): hal. 49-52.

[6] Eko, P.P., Dermawan, D., Bisono., 2014." Rancang Bangun Mesin Destilator Pengubah Limbah Plastik Menjadi Minyak". Hal. 105-110.

[7] Mustofa K.D dan Fuad Zainuri. 2014." Pirolisis Sampah Plastik Hingga Suhu 900 oC Sebagai Upaya menghasilkan Bahan Ramah Lingkungan“. Jurnal Simposium Nasional RAPI XIII.

[8] Surono, dkk. 2016. Pengolahan Sampah Plastik Jenis PP, PET dan PE Menjadi Bahan Bakar Minyak dan Karakteristiknya. Yogyakarta: Fakultas Teknik, Universitas Janabadra. Jurnal.1 (1) : 32-37. (Online). http://ejournal.janabadra.ac.id/index.php/ JMST. Diakses Pada tanggal 17 Desember 2017.

[9] Susilawati., Irfan, M., Maulina, D. 2011."Biodegradable Plastic From A Mixture Of Low Density Polyethylene (LDPE) And Cassava Stach With The Addition Of Acrylic Acid". Vol. 11(2).
[10] Sarwono, J. 2006. Metode Penelitian Kuantitatif dan Kualitatif. In J. Sarwono, Metode Penelitian Kuantitatif \& kualitatif (pp. 135-137). Yogyakarta: Graha Ilmu. 